\title{
DIRECTIONS OF DEVELOPMENT OF THE FINANCIAL SERVICES MARKET OF UKRAINE
}

\author{
Serhii Shkarlet ${ }^{1}$, Valeriia Prokopenko ${ }^{2}$, Maksym Dubyna ${ }^{3}$
}

\begin{abstract}
Development of the financial services market is an important component of the national economy's development. Within this market, credit and investment resources are formed, which are the basis of economic development of the real economy sector of the state. It is this that determines the importance of creating conditions for improving the efficiency of financial institutions, which become intermediaries between persons who have free funds and those economic entities that they need. The outlined justifies the relevance of the topic. Consequently, taking into consideration the objective of the study, the following aim of its implementation was set: to identify and substantiate the main determinants of the development of the financial services market in Ukraine. To achieve this goal, the following tasks were set and solved: to identify the main, most important, measures of transformation of the environment of financial institutions functioning; to substantiate the essence of such measures and the peculiarities of their implementation; to specify basic actions within the limits of separate determinants of the financial services market development, to describe their applied character. Method. In the course of the research, a range of different scientific methods was used. Among the general techniques, it is necessary to allocate methods of observation, comparison, abstraction. It is advisable to include the method of economic analysis, synthesis, system approach, content methods, and event analysis in specific research methods. Results. Universal priorities of financial services markets development in different countries are determined and systematized, the analysis of which made it possible to investigate perspective determinants of the development of such a market in Ukraine, peculiarities of their introduction into the functioning of the financial services sphere are described. Among these measures are the following: increase in the stability of financial institutions, increase the transparency of the functioning of producers and consumers of financial services, raising the level of financial literacy in society, reforming the state regulation system of the activities of financial intermediaries, the formation of the trust infrastructure system. Taking into consideration the received scientific outcomes, the justification of peculiarities on the implementation of these priorities in the system of the financial services market functioning in Ukraine is conducted. Practical implications. The research results obtained in the course of the research implementation regarding the possibilities of changing the financial services market for improving the efficiency of financial institutions work have an applied character, and their implementation will make it possible to form a new environment for the functioning of such economic actors. This will facilitate the transformation of financial resources to increase the formation of investment and loan funds. The results obtained can be used by public authorities that regulate the activities of financial institutions in the process of developing new strategic documents for the development of the financial services market in Ukraine. Value/originality. The conducted research is relevant, considering the significant impact of the financial services market on the development of the national economy, the proposed measures for the development of such a market are applied and can be used by public authorities in the regulation of the activities of financial institutions. This research has been conducted within the framework of the scientific work implementation Department of Finance, Banking and Insurance, Chernihiv National University of Technology, Ukraine on the following topics: "Financial stability of economic systems in crisis conditions of management" (No. 0115U001149) and "Development of financial intermediaries in the turbulent conditions of the national economy's functioning" (No. 0115U001149).
\end{abstract}

Key words: financial service, financial institution, financial credibility, financial intermediary.

JEL Classification: G20, G21

\footnotetext{
Corresponding author:

${ }^{1}$ Chernihiv National University of Technology, Ukraine.

E-mail: shkarlet@ukr.net

${ }^{2}$ International Institute of Innovative Educational Technologies, Ukraine.

E-mail:pvu9@ukr.net

${ }^{3}$ Chernihiv National University of Technology, Ukraine.

E-mail: maksim-32@ukr.net
} 


\section{Introductions}

Development of the national economy depends on a significant number of factors of exogenous and endogenous nature. However, development of the country's economy occurs only in presence of available financial resources, which use contributes to the expansion of the activity of economic entities, provides an opportunity for them to introduce innovative technologies in their own work and increase the quality of products, creates conditions to increase the demand of population for goods and services.

Formation of financial resources in the state occurs solely through the system of financial intermediaries' functioning. There are also cases of self-financing and using internal investments. However, active development of the national economy is connected with the activation of financial institutions' activity. Such intermediaries are able to transform temporary free funds of legal entities and individuals and turn them into investment resources. That's exactly why the creation of conditions for normal operation of the mentioned institutions is a guarantee for fulfilling by them their own functions and increase in volume financial resources within the national economy. Taken together, financial intermediaries and their clients form a single area of interaction - the financial services market, where the demand and proposition for financial resources among its main participants are levelled.

The financial and economic crisis of 2007-2008 had a negative impact on the financial services markets development in many countries of the world and, in general, their economies. After that, the vast majority of governments redefined the role of financial services in the development of the national economy and increased requirements for the functioning of financial intermediaries. The crisis in this area also witnessed the existence of a significant number of problems of a different nature: inefficient mechanism of state regulation of the activities of financial institutions, low level of financial literacy of the population, violation of the rights of consumers of financial services, etc. The problems outlined are universal and inherent to all countries regardless of the levels of their financial services markets development. That is why the definition of a set of key areas for improving the functioning of such markets is an urgent task for the conditions formation for the further development of national economies. There is no exception to Ukraine.

The financial services market development as a macroeconomic system is being studied by scientists for a long time. The most thorough works in this area should include the researches of Ye. A. Bobrov, Ye. P. Bondarneko, B. M. Vyshyvana, T. Yu. Zarypova, V. Zymovets, V. Ilchuk, Yu. M. Kovalenko, V. Korneyev, S. S. Krasovsky, V. Mishchenko, S. Naumenkova, I. Podsygun, I. I. Rekunenko, I. Soloshkin,
V. A. Titov, M. M. Tretiakov, V. P. Unets-Khodakivska, S. I. Yurii, G. V. Yurchuk, V. V. Yashchuk, I. Asmundson, D. Acemoglu, G. Akerlof, R. Bergner, R. Herring, A. Santomero, C. Stijn, O. Wyman, and others.

However, despite numerous works in the sphere of financial services markets development, taking into consideration variability of external conditions of this market functioning and inherent dynamism, an issue on the development of such a market is urgent, especially in current turbulent operating conditions of financial intermediaries and financial entities' functioning.

\section{Financial stability, transparency of activities, and financial literacy}

Thus, let's consider the main directions for the system development of the relations between producers and consumers of the financial services in Ukraine, which implementation will promote an increase in the work efficiency of the market of such services (Figure 1).

1. Stability growth of financial institutions.

Certainly, ensuring financial stability of all financial institutions is an important part of the formation of an effective system of financial intermediaries functioning in the country. After the financial and economic crisis of 2008-2009, the consequences of which are felt today, an overwhelming number of state regulators in the financial services markets revised the conditions for the capital formation of such institutions to increase their reliability. Appropriate decisions were also made in Ukraine.

Initially, minimum size of the authorized capital of banks was raised to 125.0 million $\mathrm{UAH}$, and later to 500.0 million UAH. Ukraine is gradually moving towards the introduction of European approaches to ensuring the stability of the financial services sector. Results were partially achieved only in the banking system through gradual withdrawal of unstable commercial banks from the financial services market of the state (and those of them which didn't correspond to new criteria determined by the NBU) (On Banks and Banking, 2000).

However, for instance, within the insurance market, there is a different situation. First, this market has not undergone such cleansing as the market of banking services and, therefore, a significant number of insurers operate on it, which in reality do not carry out active activity, are used partially for money laundering and in other, not related with insurance sphere, activity. As for the authorized capital of insurance companies, this situation has developed. In the countries of the European Union, uniform rules governing relations in the field of insurance are developed, which stipulate the establishment of rigorous legislative requirements (EU Directive). Currently, in 28 EU member states, the insurance market has an updated system of insurers' solvencyrequirements SolvencyII (Yukhymenko, 2015). 
Quantitative requirements are realized through the specific requirements to the capital of insurance companies: minimum capital requirement (MRS), which provides for an increase in authorized capital of up to 2.2 million Euros for the insurance companies engaged in risky types of insurance and for insurers engaged in life insurance this limit reaches a mark of 3.2 million Euros.

At present, for Ukrainian insurance companies, the size of the minimum statutory capital, in accordance with Article 30 of the Law of Ukraine "On Insurance" (On Insurance, 1996), for an insurer who deals with types of insurance other than life insurance, is set at an amount equivalent to 1 million Euros, and for life insurance companies, 10 million Euro at a foreign exchange rate. However, a difference between requirements for providing the minimum size of the statutory fund for Ukrainian and European companies is that the domestic legislation provides: amount in Euro is determined at the time of the authorized capital formation, and may not be reviewed later, despite the change in Hryvnia exchange rate to Euro. This has become especially relevant in the last few years. As for the European directive, then the capital adequacy of the established minimum level should be ensured on a daily basis, otherwise, supervisors for the activities of insurance companies in European countries may resort to the procedure for license withdrawal, as it jeopardizes the failure to fulfil its obligations to provide insurance services under concluded contracts (Baliev, 2016). The outlined gives grounds for asserting that in order to improve the reputation of insurers, there is a need for a profound reform of the entire insurance market. In particular, it is necessary:

1) increase the level of information disclosure about end-users not only of banking institutions but also of other non-bank financial intermediaries;

2) increase requirements for formation of statutory capital of institutions, which attract clients' funds;

3) clean up individual segments of the non-bank financial services market, especially in terms of withdrawal from such a market of really inactive credit unions, non-state pension funds, insurance companies (both life- and non-life insurance);

4) increase requirements for the functioning of rating agencies, which assign credit ratings to financial institutions and thus affect the perception of the reliability of the financial services market participants.

Hence, an increase in the level of stability of financial institutions will contribute to the development of the entire financial services market. Availability of financially able to counter the external threats of financial service providers is a key to increasing the efficiency of such a market and the rapid normalization of the work of financial intermediaries during the crisis periods of the national economy's functioning.

2. Increasing the transparency of the functioning of producers and consumers of financial services.

An important condition for the development of the financial services market in Ukraine is the increased transparency of the activities of all its participants. In scientific papers, it was decided to note the lack of

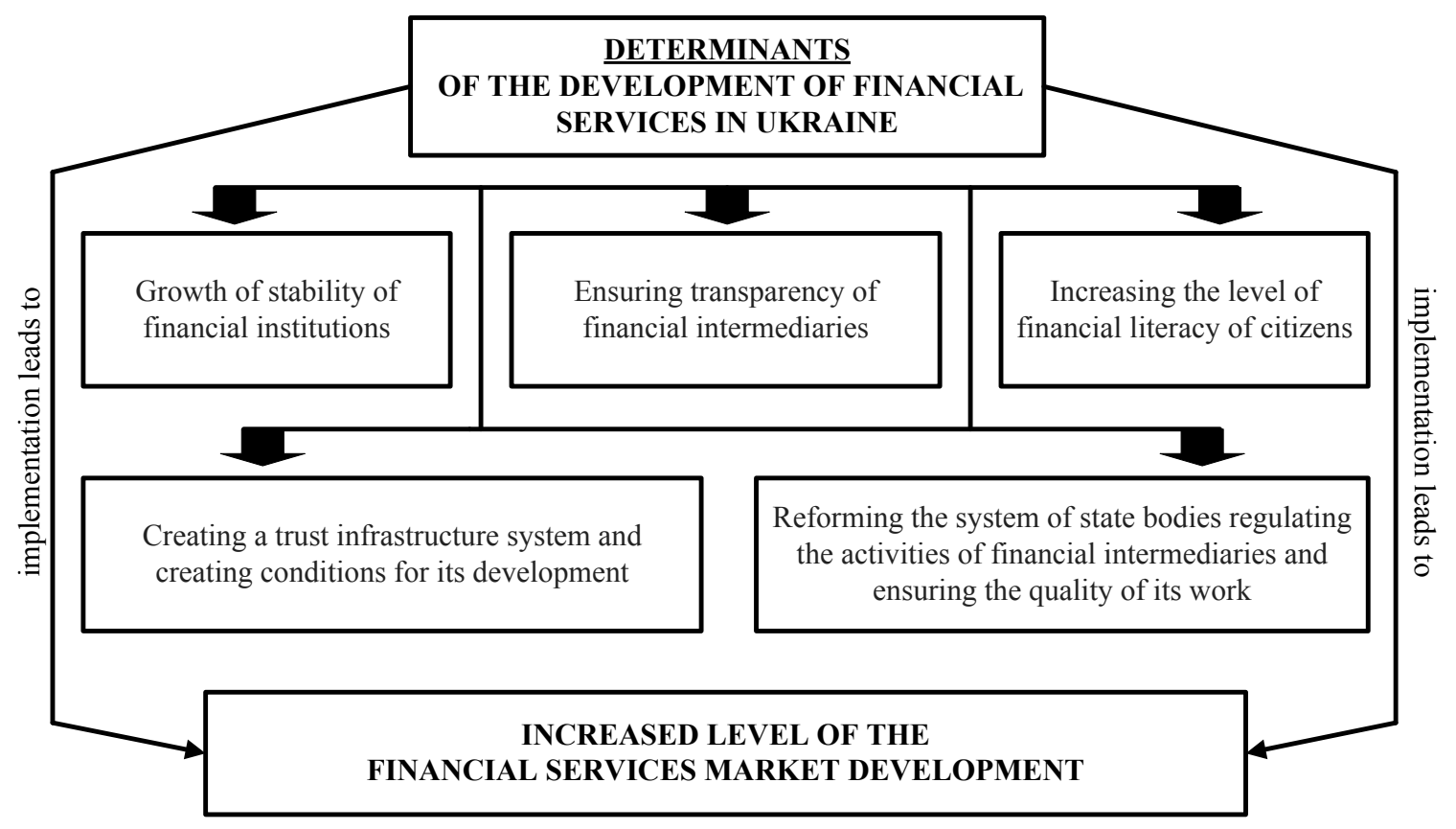

Figure 1. The main imperatives of raising confidence in the financial services market

Source: compiled by the authors (Berglof, Bolton, 2002; Cevik, Kirci, Dibooglu, Sel, Kutan, Ali, 2016; Sutton, Jenkins, 2007; Barjaktarović, Paunović, Ječmenica, 2013; Baily, Elliott, 2016; Adnan, 2006; Thalassinos, 2008) 
transparency in the activities of institutions providing financial services to clients. However, taking into account Ukrainian realities, we believe that it is also necessary to introduce mechanisms for improving the quality of information about financial services consumers.

Vishwanath T., Kauffman D. note that awareness among public authorities of the importance of transparency in the mechanisms of maintenance of welfare and development of economic markets is growing. In the economic sphere, greater availability of information, its reliability and timeliness improve resource allocation, increases efficiency and increases growth prospects. The scientific literature on financial crises recognizes that insufficient transparency is one of the factors that led to the emergence of long-term financial and economic crises (Vishwanath, Kauffman, 2001). The outlined only confirms the importance of research and increasing the level of transparency in the functioning of all economic actors.

It is worth pointing out that transparency issues concern not only the work of financial institutions and information about their clients. This also applies to the functioning of public authorities that regulate financial services markets.

It should be taken into consideration the thought of P. Shtompka: "In order to increase the transparency of a public organization, the actions of the authorities should be the most open nature. It is necessary to develop and implement an effective information policy that would serve this purpose. To do this, you need to create independent media, independent centres that collect statistics, statistical agencies, reform monitoring centres on researching public opinion" (Shtompka, 2012).

In view of the above, in our opinion, in order to increase the transparency of functioning of the financial services market, it is necessary:

1. To improve the quality of the credit history bureau's work by creating a single national system of credit records received by clients with the obligation of all credit companies and credit unions to provide relevant information.

2. To make the state databases of the population as accessible as possible for the work of financial institutions (database of convicted persons, data on court decisions in the field of financial services provision, data of the state executive service), as it happens in developed countries, where such information is not only provided in the open access, but also the access to it for institutions is synchronized, which increases the usability of its use and search.

3. To increase the transparency requirements of financial institutions, to obligatory provide to clients with information about the real value of financial services (as required by the Law of Ukraine "On Consumer Lending", 2016), but this applies only to credit services).
4. Toimplement the mechanism of regulatinginformation on the status of financial institutions by state authorities, to determine the data and requirements for their presentation obligatory for publication on official sites.

5. To create by analogy with the mechanisms of credit reference bureau for preventing fraud by clients of other financial intermediaries, except for credit. Especially this measure is relevant for the activities of risk insurance companies that deal with cases of unfair customer behaviour. That is why it is worth creating a single database of unscrupulous clients, and insurance companies are obliged to participate in its creation and work.

6. To develop a mechanism for rating activities of nonbank financial institutions in a set of indicators to increase the awareness of clients concerning their work quality.

7. To strengthen the role of self-regulatory organizations in providing information requirements to financial institutions, especially as regards the development of rules for participants in such associations.

8. To take into account the experience of publishing the owners of banking institutions, which was implemented by the NBU, and to introduce it within other segments of the financial services market, to require financial institutions to provide data on their main actual owners.

9. To create a single platform on the basis of the main self-regulatory organization (or public institution) in the field of the functioning of the financial services market to fill its information with financial intermediaries. This would enable customers to compare the terms of financial products, analyse comparative data on the performance of financial institutions, and use the information of state regulators on the functioning of individual segments of the financial services market.

10. Increase the use of the potential of modern information technologies to increase the level of information openness of financial institutions, etc.

Increasing the transparency of the work of financial institutions is an integral part of the development of the financial services market as it increases the transparency of its operation, which contributes to increasing the trust between consumers and producers of such services.

\section{Increasing the level f financial literacy in society}

Financial literacy of society is an important condition for the development of the national economy and its financial system in particular. Actually, all developed countries introduce measures to increase awareness of the specifics of the financial services use.

It is worth noting that Ukraine is to some extent an outsider in campaigns to raise the level of financial education and financial literacy for the population. The state authorities have not initiated or developed any programs in this regard, despite the fact that the introduction of educational programs for consumers is one of the first points of the implementation of the Concept on the protection of the rights of consumers of financial services in Ukraine (The concept of rights protection of consumers of financial services in Ukraine, 2009). 
In Ukraine, after the financial and economic crises of the last decade, the issue of improving the literacy of economic actors is quite acute. After 2008, a large number of individuals lost their property due to the inability to service credit obligations. This was caused by a lack of understanding of the risks of foreign currency loans. As a result, a significant number of clients of financial institutions felt guilty.

In this situation, in fact, all those involved in the functioning of the financial services markets were guilty. Customers have poorly read the terms of the loan agreements, financial institutions were not interested in explaining in detail the features of their financial products developed, state authorities did not pay enough attention to a significant increase in the volume of foreign currency loans within the entire banking system, did not affect the process.

The misunderstanding between consumers and lenders was due to the active development of collecting companies, credit reference bureaus, and significant litigation cases. Deepening of distrust between the above-mentioned subjects was accompanied by unusual cases of exceeding the assessed penalties in comparison with the initial amount of the loan.

The crisis of 2013-2014 has shown that lessons learned from 2008 were made by both clients and financial institutions. However, the bankruptcy of banks, lowering the real value of state-guaranteed funds for deposit services again halted the process of restoring confidence in the activities of financial institutions, primarily commercial banks. Because of economic transformations, banks have reduced the volume of loans for business entities. This niche was quickly taken by non-bank financial institutions (consumer lending). However, the conditions for obtaining loans in such institutions are complex and unprofitable for citizens. Interest rates on loans exceed $300-400 \%$ per annum. Customers are not always aware of the real amounts of overpayments for loans received and possible sanctions in case of late payment.

These examples demonstrate the importance of raising the financial literacy of citizens in society, understanding their specifics of the functioning of the financial services sector, the ability to determine their own real possibilities of servicing loans.

Problems of the low level of financial literacy are also relevant for developed countries where financial services markets are developing more stable. However, according to studies conducted, even in the most economically developed countries, the majority of the population has a low level of financial knowledge and often overestimates the assessment of their own knowledge and skills in consumer lending products. Simply put, most consumers around the world are not well trained to understand and manage their debt. This is a very weak foundation for building a sophisticated financial architecture (Financial literacy and awareness in Ukraine: facts and conclusions. Project on financial sector development, 2010).

Increasing the level of financial literacy makes it possible to reduce the number of cases of use of financial services by consumers who do not realize the real conditions for their provision. That is why in this area it is necessary:

1) elaborate the national program for increasing the level of financial literacy of population for the long term;

2) create state funds (for instance, on account of financial resources of the NBU) financing of individual projects as for increasing the level of financial literacy;

3 ) use the HEI potential to introduce the courses for increasing financial literacy in educational plans on specialists training (elaboration of separate themes on this subject); these issues are especially urgent for students of non-economic specialties;

4) involve international organizations for projects financing to increase the financial literacy of population, spread information through HEIs about the existence of such opportunities;

5) create within the bounds of state authorities, which regulate the activity of separate financial intermediaries, individual departments (for example, in the USA in the structure of the US Consumer Protection Bureau, the Department of consumers' education and interaction with them operates), which would be involved in relevant problem (Latkovska, 2013).

It is also interesting to note the experience of Italy in taking into account the level of financial literacy in the process of providing financial services. The client, coming to the bank, is required to complete a questionnaire which determines its level of financial literacy. And the bank does not have the right to provide him with a service that is more complex in its content than the level of literacy of the client. Otherwise, in the case of a controversial situation, the court will be uniquely on the client side. Today, it would be possible to adapt the existing experience to the Ukrainian conditions (Skapenker, 2013).

Increasing the level of financial awareness of the population contributes to increasing the resilience of financial institutions, normalizing relations between the participants in the financial services market, gradually increasing the level of trust between them. The outline only confirms the importance of implementing measures to change the current situation in this area.

\section{Reform systems of state regulation of the financial intermediaries' activities}

Development of the financial services market is impossible without the existence of reliable state regulation of its functioning. In Ukraine, an inefficient system of such regulation was formed in which the NBU implements the most important functions in the 
activities of banking institutions, which are the largest financial intermediaries in Ukraine, and National Financial Services Commission and National Securities and Stock Market Commission supervise the rest of financial institutions.

However, in addition to the NBU, financial and institutional capacity of other state bodies is limited, which also affects the quality of state regulation. The National Financial Services Commission does not have a real opportunity to clear the market of insurance services from nominally existing insurers, as the funds of clients in such institutions will be lost. It is also not possible to compensate these clients' resources, as implemented by the NBU in cooperation with the Individual Deposit Guarantee Fund. Guarantee mechanisms in Ukraine in the insurance services market have not been created.

The outlined shows that in this area it is necessary to: 1) transform the system of state regulation in the sphere of financial intermediaries functioning by means of either the creation on the basis of the NBU of a single mega regulator, as it has already been established by the countries of the former Soviet Union (Russia, Kazakhstan), or to consider the concept of constructing another, more adapted to current realities of the system of supervision over the activities of such institutions (model twin peaks becomes the most popular among developed countries);

2 ) increase the role of the state in protecting the rights of financial services consumers, effectively create and organize efficient activities of the financial ombudsman; 3) increase the level of responsibility of executive authorities for making decisions in the sphere of reforming of the financial services markets;

4) promote the introduction of new information technologies for processing the data on the financial activities of insurers;

5) change the system for collecting information on financial intermediaries, to expand it with new indicators, criteria, and mechanisms for the disclosure of such data.

Reforming the system of state regulation of the financial services markets in Ukraine is already an urgent problem and needs to be addressed, given the modern transformations of such markets and the new challenges facing the regulators that they create.

\section{Creation of a trust infrastructure system}

Trust is a major factor in the development of the financial services market. In order for such a market to develop normally, formation of trust becomes the main task, without which it is impossible to increase the efficiency of interaction between producers and consumers of financial services.

Infrastructure is a complex, dynamic system, which elements have a common goal of the activity, which consists in the formation and implementation of measures to create the preconditions for the functioning of a particular phenomenon, object, process, i.e., promoting the development of another system. Thus, the infrastructure of financial trust is a system of establishments and institutions with the same goal of the activity, which is to develop and implement measures to create the preconditions for building financial trust in society.

In Figure 2, the system of financial trust infrastructure is illustrated.

Thus, within its boundaries, it is possible to identify common elements that increase the efficiency of the work of all financial institutions and segmental organizations that play an important role in the development of individual components of the financial services market.

The main element of the trust infrastructure in Ukraine can be, for example, the Guarantee Fund for Individuals, which provides guarantees of repayment in case of insolvency of the banking institution. However, in Ukraine, in addition to this fund, there are no more guarantee mechanisms, which hold back the process of financial trust growth. That is why, in our opinion, the following should be done:

1) create insurance guarantee funds for clients' insurers of life type (On adoption of the draft Law of Ukraine on the Guarantee Fund for insurance payments under life insurance contracts, 2013);

2) create mechanisms for guaranteeing deposits attracted by credit unions (Non-bank financial institutions: Assessment of their impact on the stability of the financial system, 2012);

3 ) adapt foreign experience and introduce guarantee mechanisms for the repayment of non-state pension funds of clients;

4) consider the introduction of the above mechanisms within the framework of certain types of services of risk insurance companies (for example, as civil liability insurance for land vehicle owners, which is realized by the Motor (Transport) Insurance Bureau of Ukraine (On Mandatory Civil and Legal Liability Insurance for Motor Vehicles Owners, 2004));

5) increase requirements for the insurance intermediaries' activities, the effectiveness of their work, create an online rating system for providing their services and develop a list of unscrupulous insurance intermediaries who take fraudulent actions;

6) in general, develop a concept for building a trust infrastructure system in the state for the coordinated work of all its potential participants.

Thus, the introduction of these measures for the financial services market development will allow Ukraine to create conditions for increasing the efficiency of financial intermediaries, increase the financial literacy of population that in the complex only will promote normalization of relations between the main participants of such a market. 


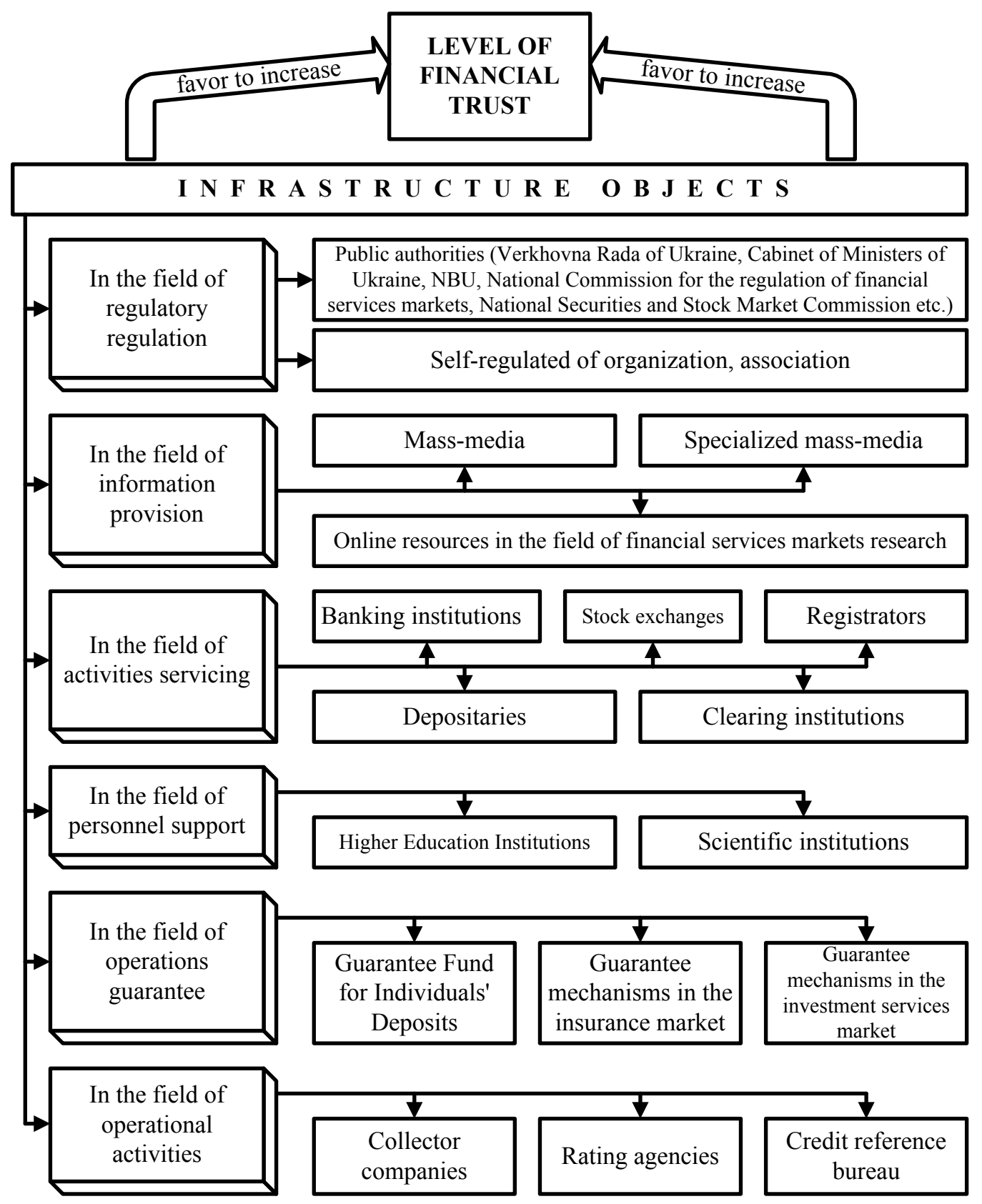

Figure 2. Classification of the main components of the system of financial trust infrastructure

Source: compiled by the author taking into consideration (Hrishova, Dubyna, Shyshkina, 2017; Prokopenko, Dubyna, 2015; Chuprykova, 2014; Shkarlet, Dubyna, Tarasenko, 2016; Sho Robert, 2000; Thalassinos, 2008; Thimann)

\section{Findings}

Within the article, directions on the development of national financial services markets are substantiated. A fragmentary analysis of the current state of the financial intermediaries' functioning in different countries has allowed identifying areas for their activities improvement and, respectively, the financial services market development. The following measures were identified as raising the level of financial literacy in society; increase in the transparency of the functioning of producers and consumers of financial services; increase in the stability of financial institutions; reforming the state regulation system of the financial intermediaries' activities; formation of the trust infrastructure system.

It is proved within the article that the outlined priority measures to improve the efficiency of financial services markets are relevant for all countries with a market economy since they solve complex problems of ensuring, first, effective interaction between financial institutions and their clients. Most of the measures were determined based on an analysis of the effects of the financial and economic crisis of 2007-2008 on the individual markets 
functioning for financial services and the peculiarities of fighting them by governments of different countries.

The article is devoted to the issue of reforming the financial services market of Ukraine, which for the last ten years has been in complicated conditions of its own functioning, which is conditioned by the influence not only of the financial and economic crisis of 2007-2008, which was by its nature worldwide, but also by the local economicpolitical crisis of 2013-2014, which affected the functioning of all types of financial institutions and led to a significant deterioration in the economic situation of the country.

\section{Conclusions}

Further perspective directions of research in the sphere of financial services markets should include the need for a deeper study of the peculiarities of the formation within the national economy of guarantee systems for ensuring the return of funds to customers in the event of the insolvency of financial service providers. Issues of their complex study and combination in the unified concept of the trust infrastructure development in the country deserve special attention.

\section{References:}

Baliev, V. Ye. (2016). Struktura kapitalu strakhovykh kompanii: vitchyzniani ta yevropeiski vymohy [Sructure of the capital insurance companies: domestic and European requirements]. Finansy, uchet, banki-Finance, accounting, banks, 1, 225-234. Retrieved from: http://nbuv.gov.ua/UJRN/Fub_2016_1_26

Hrishova, I. Yu., Dubyna, M. V., Shyshkina, O. V. (2017). Sutnist ta systema infrastrukturykredytnoho rynku Ukrainy [The essence and system of the credit market infrastructure of Ukraine]. Naukovi zapysy Instytut zakonodavstva Verkhovnoi rady Ukrainy, 4, 80-86. (in Ukrainian)

Kontseptsii zakhystu prav spozhyvachiv finansovykh posluh v Ukraini [The concept of rights protection of consumers of financial services in Ukraine]. Retrieved from: http://zakon5.rada.gov.ua/laws/show 1026-2009-\%D1\%80

Latkovska, T. A. (2013). Pidvyshchennia rivnia finansovoi hramotnosti ta finansovoi osvity - vyklyk suchasnosti [Increasing the level of financial literacy and financial education - the challenge of modernity]. Naukovi pratsi NU OIuA, 13, 429-436. (in Ukrainian)

Pro banky i bankivsku diialnist [On Banks and Banking]. № 2121-III (December 7, 2000). Retrieved from: http://zakon5.rada.gov.ua/laws/show/2121-14

Pro oboviazkove strakhuvannia tsyvilno pravovoi vidpovidalnosti vlasnykiv nazemnykh transportnykh zasobiv [On Mandatory Civil and Legal liability Insurance for Motor Vehicles Owners]. № 1961-IV (July 1, 2004). Retrieved from: http://zakon2.rada.gov.ua/laws/show/1961-15

Pro pryiniattia za osnovu proektu Zakonu Ukrainy pro Fond harantuvannia strakhovykh vyplat za dohovoramy strakhuvannia zhyttia [On adoption of the draft Law of Ukraine on the Guarantee Fund for insurance payments under life insurance contracts]. № 632-VII (October 8, 2013). Retrieved from: http://zakon2.rada.gov.ua/laws/ show/632-18

Pro spozhyvche kredytuvannia [About consumer lending]. № 1734-VIII (November 15, 2016). Retrieved from: http://zakon5.rada.gov.ua/laws/show/1734-19

Pro strakhuvannia [On Insurance]. № 85/96-BP (March 7, 1996). Retrieved from: http://zakon0.rada.gov.ua/ laws/show/85/96-\%D0\%B2\%D1\%80

Prokopenko, V. Yu., Dubyna, M. V. (2015). Kredytna infrastruktura: osoblyvosti vyznachennia sutnosti katehorii [Credit facilities: features of determining the nature of the category]. Naukovyi visnyk Uzhhorodskoho universytetu. Seriia „Ekonomika”, 1(45), 209-212. (in Ukrainian)

Skapenker, O. M. (2013). Rynok finansovykh usluh: sovremennye tendentii i perspektivy [The financial services market: trends and prospects]. Dengi i kredit, 12, 14-17. (in Russian)

Chuprykova, N. Y. (2014). Teoriia razvitiia: Differentsionno-integratsyonnaia paradigma [Theory of development: Differention-integration paradigm]. Moscow: Iazyky slavianskykh kultur. (in Russian)

Finansova hramotnist ta obiznanist v Ukraini: fakty ta vysnovky. Proekt rozvytku finansovoho sektoru [Financial literacy and awareness in Ukraine: facts and conclusions. Project on financial sector development] (2010). Kyiv. (in Ukrainian)

Shkarlet, S. M., Dubyna, M. V., Tarasenko, A. V. (2016). Orhanizatsiino-infrastrukturne zabezpechennia rozvytku silskoho hospodarstva Ukrainy [Organizational infrastructure providing of agriculture development in Ukraine]. Chernihiv: ChNTU. (in Ukrainian)

Sho Robert B. (2000). Kliuchi k doveriiu v organizatsii: rezultativnost, poriadochnost, proiavlenie zaboty [Keys to trust in the companies: efficiency, integrity, caring]. Moscow. (in Russian)

Shtompka, P. (2012). Doverie - osnova obshchestva [Trust is the basis of society]. Moscow: Lohos. (in Russian) Yukhymenko, V. M. (2015). SOLVENCY II v Ukraini: problemy vprovadzhennia vymoh do platospromozhnosti strakhovykh orhanizatsii [SOLVENCY II in Ukraine: problems of requirements implementation for solvency in insurance companies]. Naukovyi visnyk Khersonskoho derzhavnoho universytetu, 12(3), 191-195. (in Ukrainian)

Asmundson, I. (March 2011). What are financial services? Finance \& Development. Retrieved from: https://www.imf.org/external/pubs/ft/fandd/2011/03/pdf/basics.pdf

Berglof, E., Bolton P. (2002). The great divide and beyond: financial architecture in transition. Journal of Economic Perspectives, 16(1), 77-100. (in English) 
Cevik, Nuket Kirci, Dibooglu, Sel, Kutan, Ali M. (2016). Real and Financial Sector Studies in Central and Eastern Europe: A Review. Finance a uvěr-Czech Journal of Economics and Finance, 66(1), 2-31. (in English)

Christopher N. Sutton, Beth Jenkins. The role of the Financial Services Sector in Expanding Economic Opportunity. Retrieved from: https://sites.hks.harvard.edu/m-rcbg/CSRI/publications/report_19_EO\%20Finance\%20Final.pdf Dubyna, M. (2015). Scientific approach to the identification of the essence of the category „infrastructure”. Problems and prospects of economics and management, 1(1), 31-36. (in English)

Lidija Barjaktarović, Maja Paunović, Dejan Ječmenica (2013). Development of the Banking Sector in CEE Countries - Comparative Analysis, Journal of Central Banking Theory and Practice, 2, 93-114. (in English)

Marie-Renee Bakker and Alexandra Gross (2004). Development of Non-Bank Financial Institutions and Capital Markets in European Union Accession Countries. World Bank Working Paper No. 28. Washington: The World Bank. (in English)

Martin Neil Baily, Douglas J. Elliott (n.d.). The Role of Finance in the Economy: Implications for Structural Reform of the Financial Sector. Retrieved from: https://www.brookings.edu/wp-content/uploads/2016/06/11-financerole-in-economy-baily-elliott.pdf

Non-bank financial institutions: Assessment of their impact on the stability of the financial system (November 2012). European Commission. European Economy, Economic papers 472. Retrieved from: http://ec.europa.eu/ economy_finance/publications/economic_paper/2012/pdf/ecp472_en.pdf

Noureen Adnan (n.d.). The role of the financial sector in economic growth. Retrieved from: https://www.ukdataservice.ac.uk/media/263122/noureen-paper.pdf

Thalassinos, E. (2008). Trends and Developments in the European Financial Sector. European Financial and Accounting Journal, 3, 44-61. (in English)

Thimann, C. (n.d.). Financial Sectors in EU Accession Countries. European Central Bank. Retrieved from: https://www.ecb.europa.eu/pub/pdf/other/financialsectorseuaccessionen.pdf?592cfa2cb97ab362f427600 c8f216668

Vishwanath, T., Kauffman, D. (2001). Toward transparency: new approaches and their applications to financial markets. The World Bank Research Observer, 16, 41-57. (in English) 